\title{
A New Species of Spirogyra.
}

BY

WILLIAM J. HODGETTS, M.Sc.

With Plate XXII and five Figures in the Text.

$\mathrm{D}^{\mathrm{u}}$ URING May, I9I9, a number of species of Spirogyra (including S. calospora, orbicularis, nitida, longata, catenaeformis, inflata, \&c.) were observed in conjugation in a pond, which has been visited periodically for some time, at King's Norton, near Birmingham, and amongst these and other filamentous Algae occurred a Spirogyra, which not only appears to be a new species, but which presents several interesting features hitherto undescribed for the genus.

The vegetative cells of this species are $29-40 \mu$ wide, while their length is 8-I6 (sometimes as much as 22) times as great as the diameter. The filaments always show a conspicuous gelatinous sheath, which, even without the aid of stains, usually exhibits a very well-marked fibrillar structure (cf. Text-fig. 4). On mounting filaments in Indian ink it is easily seen that this sheath consists of two layers, and that the outer layer shows no obvious structure, the fibrillae being confined to the inner layer, which is also somewhat thicker than the outer. These fibrillae-which, of course, occur in the sheaths of certain other filamentous Conjugates, as well as in those of some Desmids-have a remarkable resemblance to large rod-shaped Bacteria, and give the filaments quite a furry appearance-shown in Photo I, Pl. XXII ; if a hand-lens is used, however, the fibrillar structure will be obvious in this photograph. It was rare for the whole sheath to be apparently structureless.

The most curious feature, however, is the development between every contiguous pair of cells of an $\mathrm{H}$-shaped piece of membrane, connecting the two cells together like a clamp (see Text-figs. 3, 4). This connectingclamp is a thin cylindrical piece of cell-wall, $25-30 \mu \mathrm{long}$, and furnished in the middle with a thin septum, so that the appearance in optical section is like the letter $\mathrm{H}$. Although it gives the reaction for cellulose like the rest of the cell-wall, the longitudinal portion of the clamp-like connecting-piece is rather thinner than the main cell-wall, while its transverse septum is extremely thin. Each half of the connecting-piece fits tightly like a cap

[Annals of Botany, Vol. XXXIV. No. CXXXVI. October, 1920.] 
over the end of its corresponding cell, which at this part is slightly narrowed to accommodate it, the actual diameter of the vegetative filament thus remaining fairly uniform throughout the entire length (compare Text-fig. 3 ).

The origin of this curious clamp-like organ-which, as far as the writer is aware, has never been described in any other species of Spirogyra -is as follows: The transverse septum (which is not replicate), separating two young daughter-cells, becomes rather thickened and biconvex in form, while at the same time the longitudinal cell-wall for a distance of about I $2-$ I $5 \mu$ on each side of the transverse wall becomes thickened to nearly twice its normal thickness (Text-fig. I). Two splits now arise in the thickened septum, one on each side of the original 'middle lamella' (Text-fig. 2), which itself persists as the septum of the $\mathrm{H}$-shaped connecting-clamp. Each split extends from the middle outwards, but follows the contour of the end of its corresponding cell, so that although originally transverse it turns and becomes longitudinal and finally forms the clampconnexion by turning abruptly outwards just where the thickening of the longitudinal wall ceases, as shown in Text-fig. 3. This figure (as well as Text-fig. 4) shows the slight outward curl of the edges of the connectingpiece-a character which was fairly constant.

The exact function of this connecting-piece is rather obscure, although it may be considered as a clamp-like organ tending to keep the cells of a filament together when excessive turgidity of the cells, or some other cause, is acting to produce the opposite result, i. e. the breaking up of the filament into its individual cells. It is clear that a cell must be pushed at least a distance equal to half the length of the connecting-clamp (i.e. a distance of about I 2 to $I_{5} \mu$ ) before it becomes quite free from its neighbour. Text-fig. 4 shows the ends of two disconnected cells, one of which has retained the connecting-piece as a sort of cap; a state of affairs exactly resembling that shown in the bottom right-hand corner of Photo $4, \mathrm{Pl}$. XXII. Photo 5 is especially interesting, since it shows a connecting-clamp-the septum of which is quite visible-which has just slipped off the end of a (curved) vegetative cell; and moreover the latter itself is seen to have partly slipped out of the clamp by which it is connected to the filament. Since it was rather rare to find the clamp-connexions lying free in the water, it seems that they are generally retained by one of the cells when the filaments break up.

The fibrillar structure of the external gelatinous sheath was generally denser round the connecting-clamps than elsewhere (see Photos I-3, P1. XXII), due probably to the fact that the clamps undergo no longitudinal growth, while the cells themselves often attain a relatively great length.

The cells show 5 (sometimes 4 or 6 ) narrow chloroplasts, each making a very lax spiral ( $\frac{1}{2}-I \frac{1}{2}$ turns), while the pyrenoids are large, projecting considerably from the chloroplasts, and surrounded with large angular 
starch-grains. Not infrequently certain individual cells of a filament are curiously coiled, making $\frac{1}{2}-2$ turns, although otherwise quite normal, and sometimes observed in conjugation. Photos 4, 6, and 7, Pl. XXII, show examples of these coiled cells. Coiling of the filaments of various filamentous Algae has been recorded by W. and G. S. West, the specimens

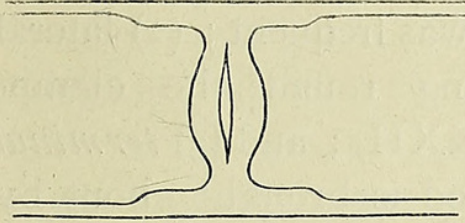

Fig. I.

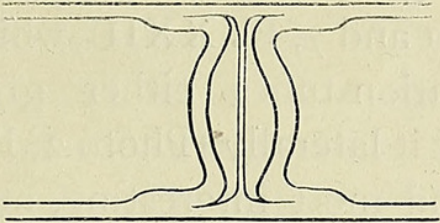

Fig. 2 .

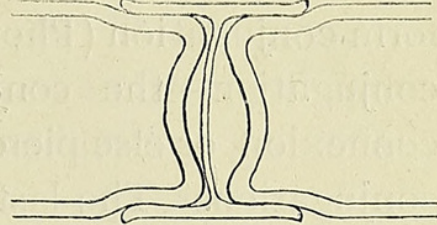

Fig. 3.

TeXT-FIGs. I-3. Spirogyra colligata, sp. nov. Successive stages in the development of the $\mathrm{H}$-shaped connecting-clamp between contiguous pairs of cells (the process is described in the text). $\times$ 500. (Somewhat diagrammatic.)
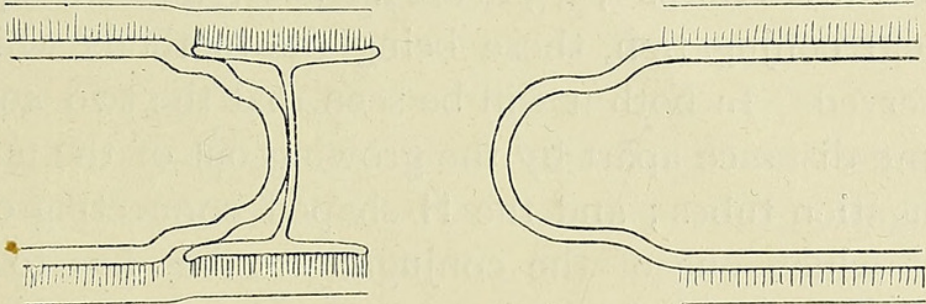

TEXT-FIG. 4 Spirogyra colligata, sp. nov. Ends of two contiguous cells which have been pulled apart, showing the $\mathrm{H}$-shaped clamp-connexion retained on the end of the left-hand cell. The gelatinous sheath with its fibrillar structure is shown (in the other figures it has been omitted): $\times 500$. (Somewhat diagrammatic.)

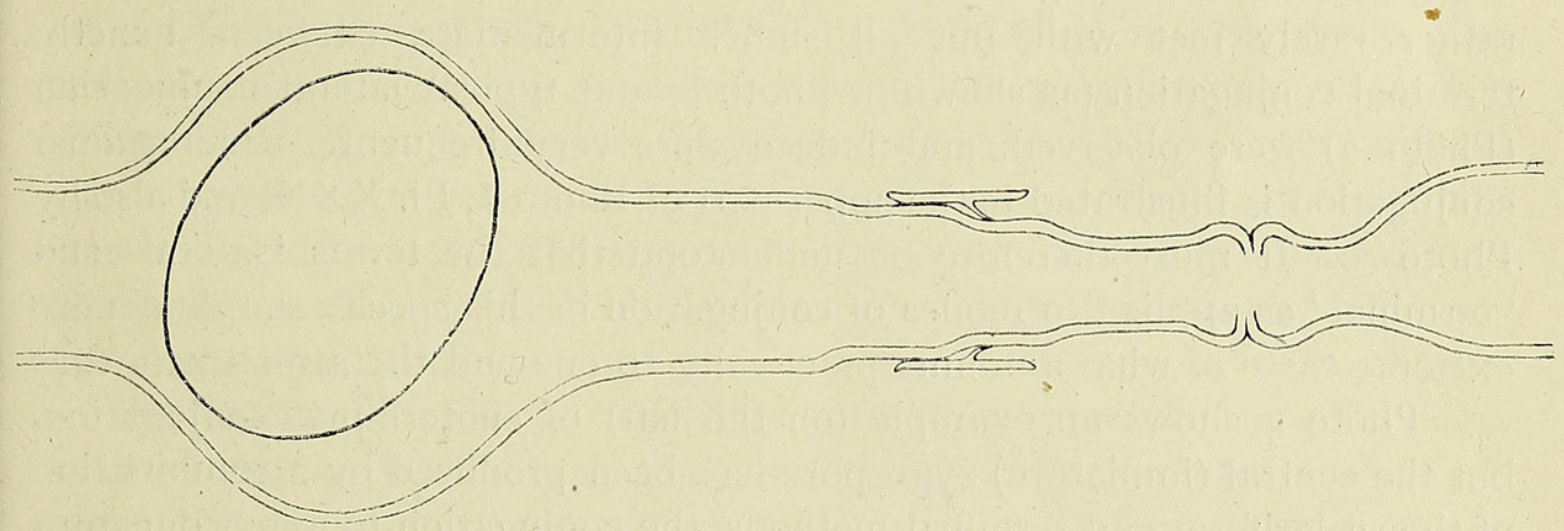

TEXT-FIG. 5. Spirogyra colligata, sp. nov. Terminal conjugation. Only the end of the empty male gametangium is shown. $\times 400$. (Somewhat diagrammatic.)

occurring in the plankton of lakes, and the coiling considered to be 'a limnetic character developed to augment the floating capacity of the filament'. ${ }^{1}$. This view can hardly be applied to the coiled cells of the present Alga, since the filaments occurred, amongst other filamentous forms, at the shallow margin of a pond, and generally in less than 12 inches of water. Moreover, in the present case the coiling was generally limited

1 W. and G. S. West, in Proc. Royal Soc., B., vol. 1xxxi, r9o9, p. 195. Coiled filaments have been recorded in species of Mongeotia, Anabaena, Lyngbya, and Melosira. 
to a single cell of a filament, and in several cases it was clearly seen that these curved cells were coiled round another filament of the same species. This can hardly be considered accidental, and it appears that this coiling may be a contact phenomenon serving to grapple the filaments together, and thus aiding scalariform conjugation.

Three modes of conjugation were observed in this species: (I) scalariform conjugation (Photos I and $7, \mathrm{Pl}$. XXII), which was frequent ; (2) lateral conjugation-the conjugation-tubes either growing round the clampconnexion, or else piercing it laterally (Photo 2, P1. XXII) ; and (3) terminal conjugation. The last, and most interesting, method is brought about by the growing out of one extremity of a cell, in the form of a conjugationtube, through the septum of the $\mathrm{H}$-shaped clamp, to meet, and eventually fuse with, another terminal conjugation-tube put out by the adjacent cell of the same filament. Photos I, 3, 5 to 8, P1. XXII, show examples of terminal and subterminal conjugation, these being the methods which were most frequently observed. In both it will be seen that the two conjugating-cells are pushed some distance apart by the growing out of the terminal or subterminal conjugation-tubes; and the $\mathrm{H}$-shaped connecting-clamp, through the septum of which one of the conjugation-tubes has to pass, is either pushed off both the cells and remains transfixed somewhere on the conjugation-tube-shown very well by Photo $8, \mathrm{Pl}$. XXII-or else it persists on the end of one of the cells, as shown in Photos 6, 7, and in Text-fig. 5 .

True lateral conjugation, such as is shown in Photo 2, Pl. XXII, was rather rarely met with, but all stages intermediate between exactly terminal conjugation (as shown in Photo 8) and typical lateral conjugation (Photo 2) were observed, and indeed were very frequent. Subterminal conjugation is illustrated in the upper part of Photo $1, \mathrm{Pl}$. XXII, and also by Photo 5. It must therefore be understood that the terms 'lateral' and 'terminal' as applied to modes of conjugation in this species simply denote extreme cases of what amounts practically to one and the same method.

Photo 4 shows an example (on the left) of subterminal conjugation, but the central (immature) zygospore has been produced by a combination of the scalariform and terminal methods, the conjugation-tube put out from the female gametangium-which is the end-cell of a filament-being approximately terminal. This, however, is an abnormal mode of conjugation, and was observed only twice.

Terminal (or subterminal) conjugation does not appear to have been described as a normal method of conjugation in any other species of Spirogyra, as far as the present writer is aware. It should be noted that an attempt at this method of conjugation in any other species of the genus - whether provided with replicate end-walls or not-would probably fail owing to the two conjugating-cells being pushed apart before a firm union became established between the conjugation-tubes. In the present species, 
however, on account of the $\mathrm{H}$-shaped clamp, the cells are more firmly joined together-as stated above, one could be pushed a distance of $I 2-I 5 \mu$, or even more, before becoming actually free from its neighbour-and probably this it is which enables the two terminal conjugation-tubes to fuse together and effect a firm union.

The zygospores are lenticular in shape, being quite circular in front view but broadly oval in the side view (see Text-fig. 5). The wall of the mature zygospore is three-layered, as in other species, the outer and inner layers being thin, smooth, and colourless, while the middle layer is thick, brown in colour, and verruculose, presenting a wavy appearance when viewed in profile.

The female gametangium, as shown in the photographs on Pl. XXII, is swollen in the middle, often to a considerable extent and much more than is necessary to accommodate the zygospore. The only other species of the genus which have the female cells swollen in this way, and with which the species now being described might be confused on a superficial examination, are Spirogyra pellucida, (Hass.) Kütz., ${ }^{1}$ and S. sphaerospora, Hirn. ${ }^{2}$ The present species differs from $S$. pellucida in its narrower cells, in the presence of the $\mathrm{H}$-shaped clamps between the cells, and in the possession of (generally) 5 chloroplasts. S. sphaerospora has a single chloroplast, smooth-walled zygospores which are 'vollkommen kugelig', and no $\mathrm{H}$-shaped pieces between the cells.

The writer considers this new species to be one of the most highly evolved, if not the highest, of all the known species of Spirogyra. The curious $\mathrm{H}$-shaped connexions - not described for any other species-which tightly clamp the cells together, as well as the variety of modes of conjugation, seem to support this view. At any rate the species is of particular interest, since it shows that the genus Spirogyra is much more plastic, both in vegetative structure and in methods of conjugation, than has hitherto been generally supposed.

The species has been called S. colligata, on account of the cells being 'bound together' by the $\mathrm{H}$-shaped connecting-pieces; and the following is a diagnosis of it:

\section{SPIROGYRA COLLIGATA, sp. nov.}

Sp. lubrica, pallide viridis, cellulis vegetativis plerumque rectis, at interdum spiraliter curvatis, diametro $8-16(-2,2)$-plo longioribus, extremitatibus non replicatis (sed ut plurimum plus minusve alte incurvis); cellulis binis contiguis confibulis $\mathrm{H}$-formibus, e membrana cellularum externa efformatis, arcte colligatis; chromatophoris 5 (interdum 4 aut 6 ), angustis,

1 See West, G. S. : Journ. Bot., I899, p. Io9.

${ }^{2}$ Hirn: Acta Societatis pro Fauna et Flora Fennica, xi, No. Io, p. Io. I am indebted to the late Professor G. S. West for information concerning this species, 
pyrenoidibus magnis instructis, anfractibus laxissimus $\frac{1}{2}-1 \frac{1}{2}(-2)$; coniugatione scalariformi vel laterali vel terminali ; cellulis fructiferis parte mediana valde tumidis; zygosporis lentiformibus, a fronte visis orbicularibus, a latere late ovalibus, cellulas fructiferas non complentibus, membranae strato mediano verruculoso.

$$
\begin{aligned}
& \text { Crass. cell. veget. } 29-40 \mu \text {; } \\
& \text {, " } " \quad \text { fruct. circa } 90-\text { - } 00 \mu \text {; } \\
& \text { Diam. zygosp. } 50-80(-90) \mu \text {. }
\end{aligned}
$$

Hab. in stagno King's Norton, Worcestershire (May I9I9).

My best thanks are due to Mr. W. B. Grove, M.A., for his kind interest and help during the preparation of this paper.

\title{
DESCRIPTION OF PHOTO-MICROGRAPHS OF SPIROGYRA COLLIGATA, SP. NOV., IN PLATE XXII.
}

\author{
Illustrating Mr. William J. Hodgetts's paper on a New Species of Spirogyra.
}

(All these figures are from untouched photographs.)

Photo I. The upper zygospore has been formed by semi-terminal conjugation-the empty male gametangium on the left is only partly shown. The lower zygospore is the result of scalariform conjugation. The furry appearance of the male cell is due to the pronounced fibrillar structure (seen better if the photograph is examined with a hand-lens) of the gelatinous sheath. Note the $\mathbf{H}$-shaped clamp-connexion which has persisted on the end of the (lower) female gametangium. $\times 90$.

Photo 2. True lateral conjugation, the empty male gametangium being on the right. $\times 90$.

Photo 3. Semi-terminal conjugation. $\times 82$.

Photo 4. The zygospore on the left has been produced by terminal conjugation (the male cell is only partly shown on the left). The immature central zygote has been produced by an abnormal method compounded of the 'terminal' and 'scalariform' methods, the female conjugation-tube being terminal. At the bottom right-hand corner of the photo the ends of two disjointed cells, with the $\mathrm{H}$-shaped clamp (loosely fitting on end of upper cell) which formerly joined the cells, will be seen (cf. Text-fig. 4). Two examples of coiled cells are also shown. $\times 90$.

Photo 5. Semi-terminal conjugation. The (curved) end-cell is attached very loosely to the filament, and an $\mathrm{H}$-shaped clamp-connexion, which has just slipped from its extremity, is shown. $\times$ IIO.

Photo 6. Terminal conjugation and a coiled vegetative cell. $\times 85$.

Photo 7. Scalariform and two examples of subterminal conjugation are illustrated. Two coiled cells are also present. $\times 9^{\circ}$.

Photo 8. Terminal conjugation (the empty male gametangium is only partly shown). The $\mathrm{H}$-shaped clamp has been pushed off the ends of the conjugating-cells, and is seen transfixed on the conjugation-tube between the two gametangia. $\times 90$. 

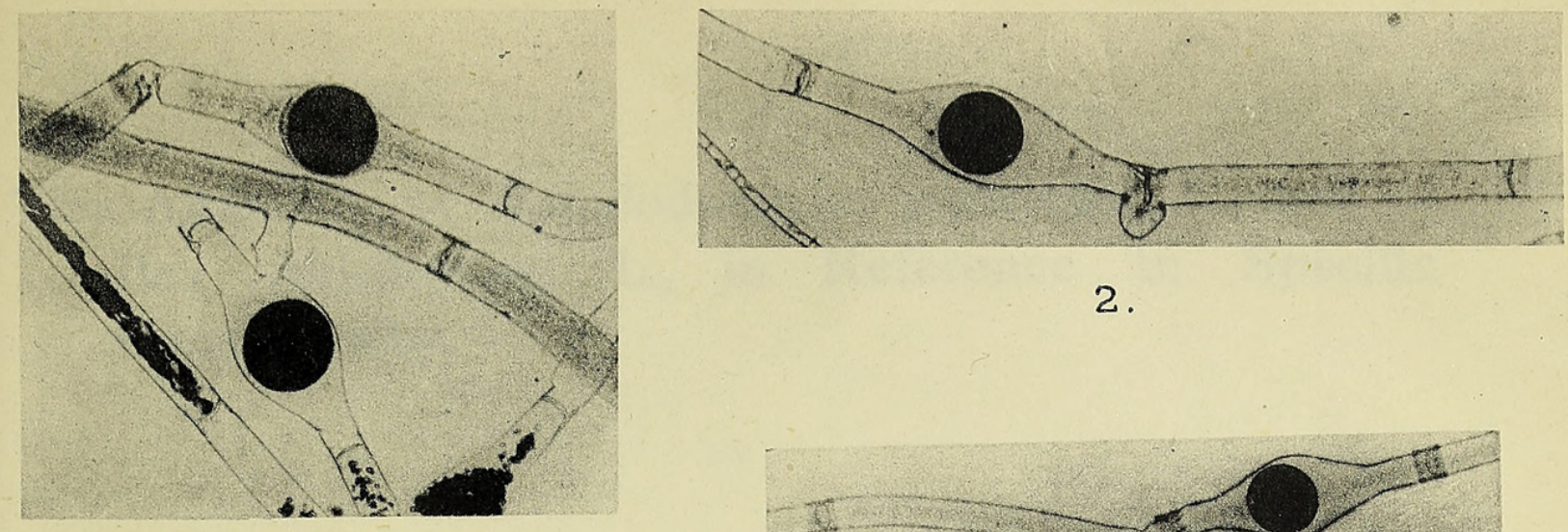

2.

1.

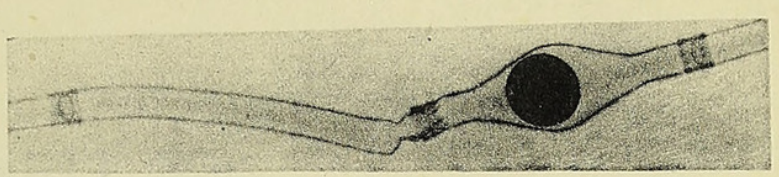

3.
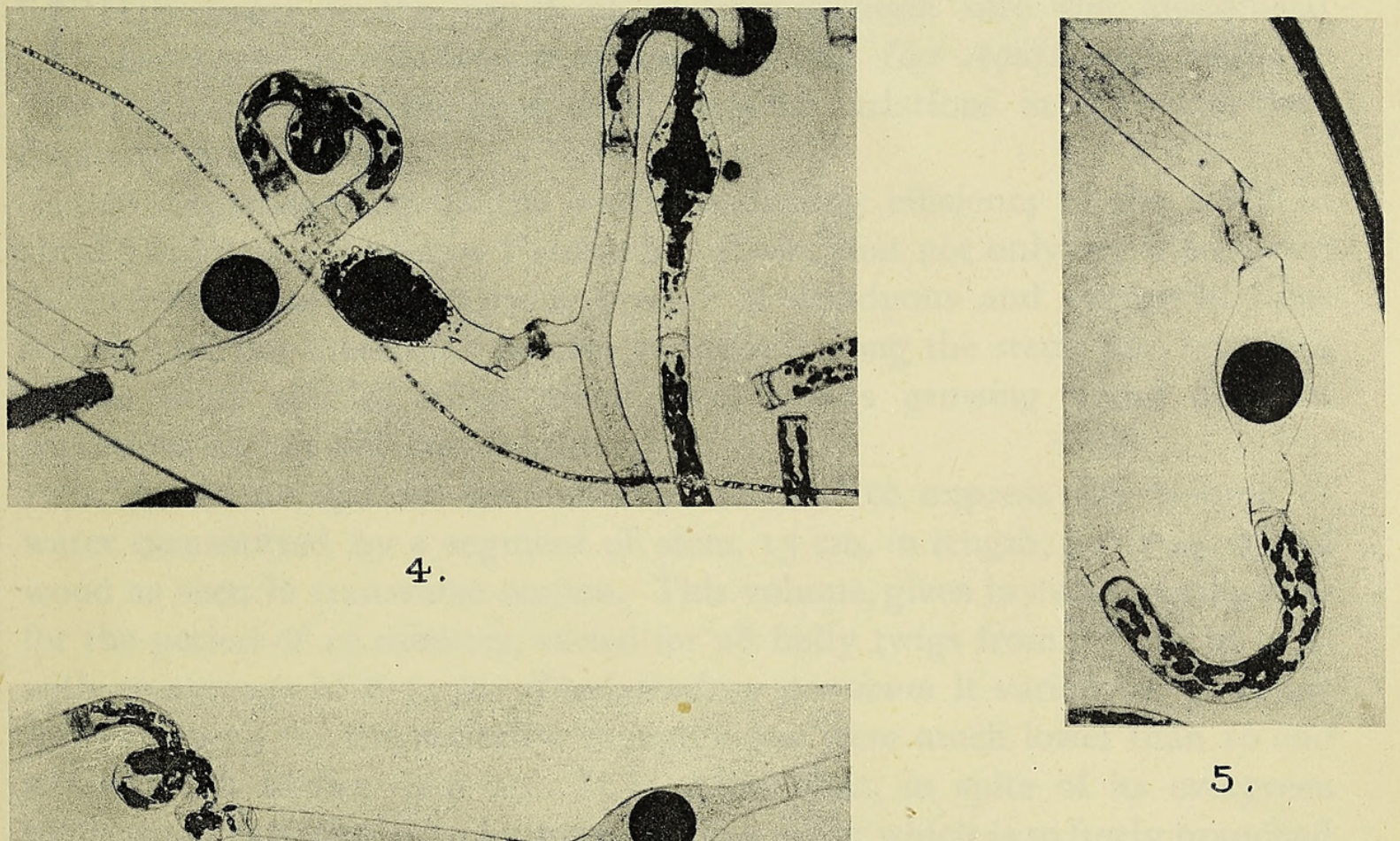

4.
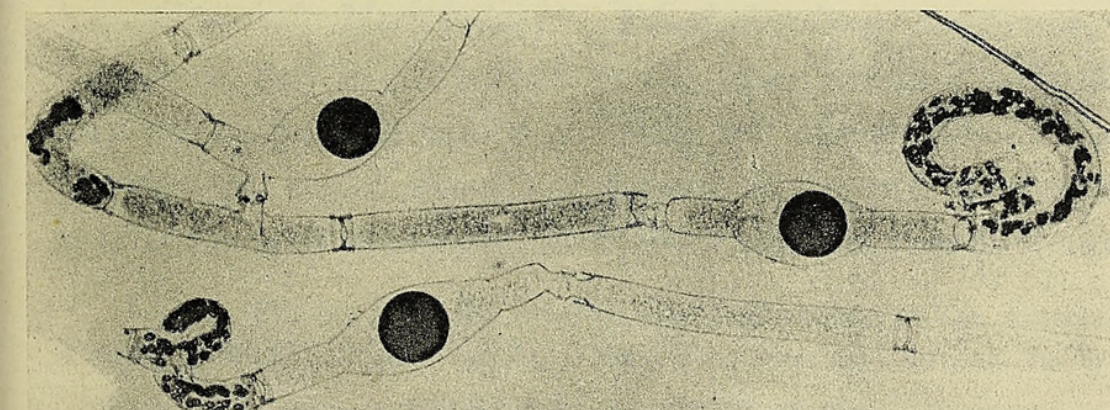

W.J.H photo.

7.

HODGETTS-SPIROGYRA. 


\section{$2 \mathrm{BHL}$ Biodiversity Heritage Library}

Hodgetts, William J. 1920. "A new species of Spirogyra." Annals of botany 34, 519-524. https://doi.org/10.1093/aob/os-34.4.519.

View This Item Online: https://www.biodiversitylibrary.org/item/236972

DOI: https://doi.org/10.1093/aob/os-34.4.519

Permalink: https://www.biodiversitylibrary.org/partpdf/320305

\section{Holding Institution}

Smithsonian Libraries

\section{Sponsored by}

Biodiversity Heritage Library

\section{Copyright \& Reuse}

Copyright Status: Not in copyright. The BHL knows of no copyright restrictions on this item.

This document was created from content at the Biodiversity Heritage Library, the world's largest open access digital library for biodiversity literature and archives. Visit BHL at https://www.biodiversitylibrary.org. 